Kudzai Mafuwe ${ }^{2 *}$, Edwin Tambara ${ }^{3}$, Fortunes F. Matutu ${ }^{4}$, Cedric Maforimbo ${ }^{56}$, Joshua Tsamba7, Cynthia Mapendere ${ }^{8}$, Sydney Moyo ${ }^{9}$

\title{
Community assembly of adult odonates in lacustrine systems of an understudied world heritage site of south-eastern Zimbabwe
}

https://doi.org/10.23797/2159-6719_24_9

Received: 1 October 2020 - Accepted: 31 December 2020 - Published: 7 July 2021

\begin{abstract}
Odonata (dragonflies and damselflies) are efficacious for management and conservation efforts in freshwaters. In recent times, increased effort has gone into enhancing awareness, data and information on dragonflies among scientists and policymakers. Here, we examined the Odonata community of dams within the Matobo National Park, a world heritage site in southern Zimbabwe. Specifically, we determined diversity of larval and adult odonate in five dams over one year. Several physico-chemical parameters were measured, including $\mathrm{pH}$, total dissolved salts (TDS), electrical conductivity (EC). Further, we assessed how habitat types (i.e., detritus, sand, gravel, plant type) affect Odonata communities. In addition, surveys were conducted to identify critical threats to Odonata in the Matobo National Park and surrounding areas. Broadly, results showed that Odonata nymphs and volant adults did not change predictably across all sampling occasions. Further, $\mathrm{pH}$ was positively correlated with Libellulidae and Platycnemididae, whereas TDS and EC were positively correlated with Libellulidae, Platycnemididae and Macromiidae. Contrariwise, Gomphidae were found to be negatively correlated to TDS, EC and $\mathrm{pH}$. The threat analyses identified natural system modifications, agricultural expansion and intensification, as well as human intrusions and disturbance as the major threats to Odonata and freshwater resources in Matobo National Park. Taken together, these data provide baseline data that will be useful for future monitoring of threats and subsequently conservation strategies in the Matobo National Park and other protected areas in Southern Africa.
\end{abstract}

Keywords: Odonata, dragonfly, Matobo, protected areas, biodiversity, physico-chemical, bio-indicator

\section{Introduction}

Odonates (dragonflies and damselflies), as one of the earliest winged insects from the middle Permian (Kalkman et al., 2008) are prominent in many types of freshwater habitats globally (Dijkstra et al., 2014). Owing to their complex life histories, odonates are good bio-indicators of the overall health of an ecosystem in both terrestrial and aquatic habitats. Since they inhabit both aquatic and terrestrial environments, they may better reflect environmental variations in different ecosystems.

Dragonflies and damselflies have been successfully used as major components in assessing the ecological condition of aquatic biotopes in some African countries (e.g., South Africa and Kenya; Clausnitzer, 2003; Suh \& Samways, 2005). Dragonflies and damselflies have also been promoted as an easy-to-learn tool in environmental education programs. For instance, the Dragonfly Biotic Index

1 University of Zimbabwe, Department of Biological Sciences, Mt Pleasant, Harare, Zimbabwe

2 Natural History Museum of Zimbabwe, Park Rd, Bulawayo, Zimbabwe

3 African Wildlife Foundation, Washington DC, United States of America

4 Forestry commission Zimbabwe, Cnr 2nd Ave/Khartoum Street PO Box 290 Gwanda

5 Linacre College, University of Oxford, St. Cross Road, Oxford, OX1 3JA, United Kingdom

6 School of Wildlife Conservation, African Leadership University, Kigali Innovation City, Special Economic Zone, Kigali, Rwanda

7 Chinhoyi University of Technology Department of Biology, School of Natural Sciences and Mathematics, P. Bag 7724, Chinhoyi.

8 University of Pretoria, Lynnwood Rd, Hatfield, Pretoria, 0002, South Africa

9 Rhodes College, Department of Biology, Memphis, Tennessee, United States of America

* corresponding author: Email: kudzimaffyagmail.com 
(DBI), a biomonitoring tool that uses the presence of dragonfly at a site to define the health of that freshwater ecosystem, was developed for South African freshwater systems (Simaika \& Samways, 2009; Samways \& Simaika, 2016). The aforementioned works have paved the way for projects on water conservation using bioindicators, especially in developing countries, where pressures on freshwater systems are prevalent (Clausnitzer et al., 2017).

The recognition that Odonata species as useful indicators of ecosystem health in environmental impact assessments and monitoring programs, has seen an increased effort in making information on dragonflies available to scientists, conservation area managers and policymakers (Cardoso et al., 2020; Córdoba-Aguilar, 2008). However, effective use of odonates in conservation efforts, requires baseline information on the diversity and abundance of these species that are currently understudied in most of the African continent (Rodríguez-Tapia et al., 2020; Samways \& Steytler, 1996).

The distribution of various species of Odonata is highly variable across spatio-temporal scales. In Africa, 15 families have been recorded (Dijkstra \& Clausnitzer, 2014; Dijkstra et al., 2015) with evidence that some families are restricted to cool streams or rivers, while others are restricted to ponds or still clear waters, and some to marshy places. High diversity of Odonata species is often at sites that offer a wide variety of microhabitats.

Many biotic and abiotic factors affect the distribution of aquatic insect larvae (sensu Schriever, Cadotte, \& Williams, 2014). For instance, acidity of the water, the amount and type of aquatic vegetation, the temperature, and water flow all affect the distribution of Odonata larvae and can all potentially affect the distribution of aquatic insect larvae (Schriever, Cadotte, \& Williams, 2014). While some species are affected by a myriad of biotic and abiotic factors, some species can tolerate a broad range of conditions (Acquah-Lamptey, Kyerematen, \& Owusu, 2013). Broadly, dragonflies tend to be much more sensitive to pollution than damselflies (Acquah-Lamptey, Kyerematen, \& Owusu, 2013).

Dragonflies occupy a wide range of habitats with many species and families having their specific environmental preferences. The habitat association of dragonflies and damselflies in Africa has been described by many researchers (e.g., Deacon, Samways, \& Pryke, 2020; Vorster et al., 2020). Moreover, several studies have shown that species assemblages of odonates are influenced mainly by aquatic and terrestrial vegetation (Paice, Chambers, \& Robson, 2017). Studies have shown that adult diversity and abundance is often positively correlated with local abundance of vegetation (Remsburg $\&$ Turner, 2009). The adults of some species require emergent or waterside plants to use as perches (Pritchard \& Kortello, 1997; Worthen \& Morrow, 2016). For instance, McCrae \& Corbet, (1982) documented that the adult males of Tetrathemis polleni (Selys) will compete for the tops of the sticks as perches will keep returning to the same perch even after a disturbance. Other species such as The Large Red Damsel (Pyrrhosoma nymphula) need specific submerged or floating macrophytes to lay their eggs on (Rehfeldt, 1990). Different odonate species can also occupy the same small area if each species can use a different substrate for perching and oviposition (Martens, 2002).

To date, there are many taxonomic studies on odonate larvae and imagoes of Zimbabwe (Pinhey 1961; Pinhey 1984; Tarboton \& Tarboton, 2019) and an extensive collection of odonatan species collected around Zimbabwe by world renowned collectors like Dr. Elliot Pinhey, whose samples are all deposited in the Natural History Museum of Zimbabwe. Some of the aforementioned collections carry useful occurrence records that have been used in predictive modelling for the distribution of endemic species such as Chlorestes elegans (unpublished data, Mafuwe 2020). Nonetheless, most records date back at least 30+ years (Pinhey 1961; Pinhey 1984; Kipping, Dijkstra, Clausnitzer, Suhling, \& Schütte, 2009; Dijkstra \& Clausnitzer, 2014). A few studies in Zimbabwe have also focussed on quantitative habitat correlates of diversity and habitat associations. For example, researchers have assessed the effect of industrial waste and temperature fluctuations on Odonata diversity in Zimbabwe (Dube, Makaka, \& Sibanda, 2010; Makaure et al. 2015). However, the ecological studies on richness and distribution at national levels remain few; these studies are also few in lacustrine systems, especially those in protected areas.

Strikingly, in Zimbabwe as in many other parts of sub-Saharan Africa, biodiversity conservation priority lists, omit Odonata (Burgess et al., 2005; Mutasa \& Ndebele-Murisa, 2015), even though they are known to occur in these conservation areas (Bernard \& Daraż, 2018; Dijkstra \& Clausnitzer, 
2014). Considering, a few species are listed as threatened or data deficient in the IUCN Red list (IUCN, 2017) cursory data on odonate diversity and distribution will be useful for the conservation of odonate species, along with their aquatic habitats.

Determining the factors that may affect the presence of a species is crucial to determine the species that can be affected by environmental or habitat changes (Cardoso et al., 2020; Nagy et al., 2019). In this study, we describe shifts in adult and larval Odonata abundances in an understudied world heritage site in Zimbabwe over one year (across three seasons), as well as determine the relationships that exists between water quality, aquatic habitats and these odonate fauna. Specifically, we aimed to (i) describe the odonate fauna in terms of abundances and diversity over a one-year period, (ii) assess relationships between Odonata and key environmental and habitat variables and, (iii) assess current and future threats to Odonata diversity. Along with these objectives we predicted that diversity of odonate nymphs would be higher in the cold seasons where emergence of odonates is low. Conversely, we predicted that volant dragonflies would have higher diversity in the warmer months when emergence of odonates is high. Outcomes from this research are expected to form the basis for Odonata research and subsequently contribute to conservation actions through long-term ecosystem monitoring of aquatic fauna. This study is also a first step towards identifying bioindicators urgently needed for wetland monitoring in Zimbabwe.

\section{Material and methods}

\section{Study Area}

The Matobo Hills in Zimbabwe was declared a World Heritage Site in August 2003 and is characterized by a rocky landscape with a unique natural and social heritage (Sagonda \& Pegg, 2015). The Matobo Hills comprise of wooded valleys and boulders and are a place of very high biodiversity of flora and fauna (Matobo Hills Management Plan, 2015). The world heritage site covers an area of about $3100 \mathrm{~km}^{2}$, of which $424 \mathrm{~km}^{2}$ is a National Park (Figure 1), the remainder being mostly communal land and a small proportion of commercial farmland (Gambiza \& Nyama, 2006). Part of the national park is set aside as $100 \mathrm{~km}^{2}$ of game park. The park also extends along the Thuli, Mtshelele, Maleme and Mpopoma river valleys (Figure 1).

\section{Sample collections}

We collected samples for Odonata nymphs and adults at the start, mid and end of each season across five dams (Figure 1) between May 2016 and April 2017. Sample collection was designed to coincide with Zimbabwe's three climatic seasons (hot wet season from mid- November to March, a cold dry season from April to July, and a hot dry season from August to mid-November). Sampling was conducted between 10:00 hours and 16:00 hours when adult Odonata are mostly active.

At each of these dams, six sampling points were selected within 100 meters of the main access points and were at least $200 \mathrm{~m}$ apart. Using a South African Scoring System (SASS) net (35 by $35 \mathrm{~cm}$ and mesh size of $0.8 \mathrm{~mm}$ ), odonates were disturbed and encouraged to drift by agitating the substrate using the traveling kick method for a 5 -min period over a $5 \mathrm{~m} 2$ area of the pool. Contents from the aquatic nets were emptied into a pan to pick out the nymphs using forceps and a total of six scoops were done at each sampling point. Specimens were preserved in ethanol 1 and transported to the laboratory for counting and identification to families and morphospecies. At each point recordings were made on micro-habitats according to the presence or absence of aquatic plants as well the bottom substrates (i.e., detritus, sand, gravel) from which the nymphs were collected. The following water quality parameters were measured at each point using a multiparameter meter (YSI Inc, USA): $\mathrm{pH}$, Total dissolved salts, electrical conductivity. 


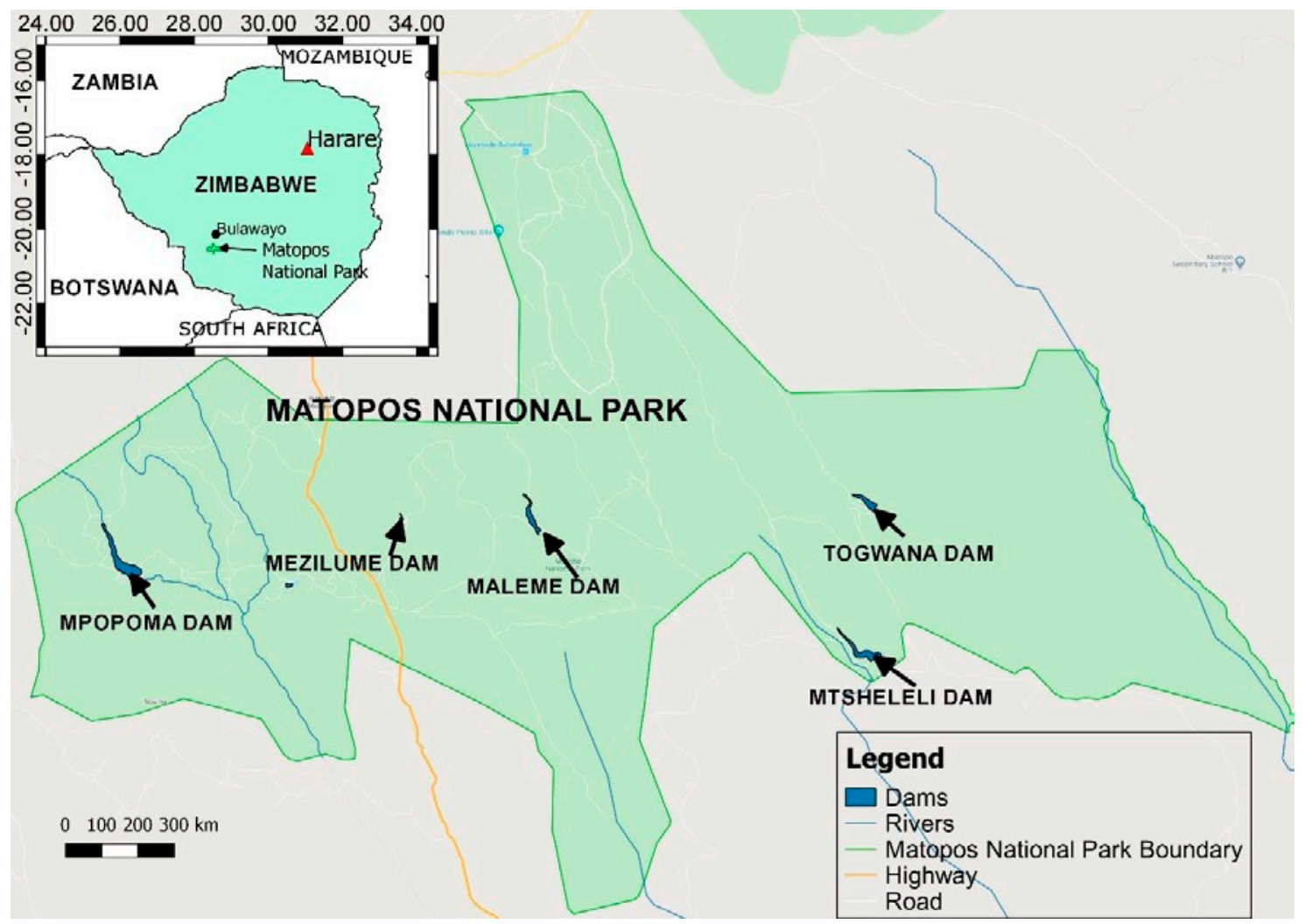

Figure 1. Study area (Matobo National Park) showing five dams sampled across three seasons (hot wet, cold dry, hot dryl between May 2016 and April 2017.

For observations of adult specimens, sampling was done along two, $500 \mathrm{~m}$ transects on both sides of the dam, with a width of $5 \mathrm{~m}$ perpendicular from the water systems. Odonata species encountered were identified and counted. Identification of species was primarily done using close-focusing binoculars and field guides. Where necessary one individual of each species was caught and examined using a hand-lens to confirm identification and subsequently released. Species were photographed to provide a permanent record of identification. Where further identification was required, voucher specimens were captured and transported in labelled paper envelopes for further identification using keys by Dijkstra \& Clausnitzer (2014). The Dragonfly Biotic Index (DBI) for each species was also noted. The Dragonfly Biotic Index is a compound index based on three criteria: geographical distribution, conservation status and sensitivity to change in habitat. It ranges from a minimum of 0 to a maximum of 9. A very common, widespread species that is highly tolerant to human disturbance scores 0 . In contrast, a range-restricted, threatened and sensitive endemic species scores 9 (Samway, 2008).

To obtain cursory information on some of the threats that each of our study sites were facing we used definitions and hierarchical classification as described by Salafsky et al., (2008). A Standard Lexicon for Biodiversity Conservation: Unified Classifications of Threats and Actions was used to describe and to categorize threats and actions. This method was chosen to allow for a consistent framework for threats to ensure consistent identification of shared threats across protected areas (Table S5 in Supplementary file). All impact scores (negligible, low, medium and high) were based on estimates whereby we interviewed managers, ecologists and conservationists working within Matobo National Park as well as communities in surrounding areas (sensu Ervin, 2003). 


\section{Data analysis}

The Simpson Diversity Index (Morris et al., 2014; Simpson, 1949) was used to determine the diversity for the adults and nymphs per each sample. After testing for normality using the KolmogorovSmirnov normality test and the Shapiro test, all data were found to deviate significantly from a normal distribution. The differences their seasonal variations across the one-year period were compared using nonparametric tests.

The relationship between diversity indices and the physico-chemical parameters were determined using correlation analyses. To analyze the association of different families to the environmental variables at the dams studied, we used a canonical component analysis (CCA) using the vegan package in R (Oksanen et al., 2010).

The relative abundance was calculated for each microhabitat by dividing the number of individuals observed in each microhabitat by the total numbers of individuals observed in that family. Indicator value (IndVal) analysis (Dufrêne \& Legendre, 1997) was used to identify if any of the species were especially associated with any of the microhabitats. The IndVal indicator attains the maximum value (1.00) when all the individuals of a species are found in a single treatment (high specificity) and when the species occurs in all replicates of a treatment (high fidelity). The IndVal computations ('labdsv' package) were performed in $\mathrm{R}$, version 3.5.0 ( $\mathrm{R}$ Core Team, 2019). A randomization procedure assessed the significance of the indicator value of each species. Species that achieved a significant IndVal score were selected for interpretation.

\section{Results}

\section{Nymph composition (Objective 1)}

Six Odonata families were identified from a total of 427 individual nymphs recorded during the entire sampling period. The highest abundance of Odonata (166 individuals) was recorded during the cold, dry season followed by the hot-dry season (138 individuals) and the least during the hot-wet season (123 individuals). Six families were recorded in the cold-dry season, whereas only five families were recorded in the hot-dry season and the hot-wet season. Based on the total number of individuals recorded, Gomphidae was the most abundant family during the entire sampling period for the nymphs (166 individuals), followed by the Coenagrionidae and Libellulidae families with 128 and 98 individuals recorded respectively. The Gomphidae family had the highest species abundance recorded in the cold-dry season and the Hot-wet season, whereas the Coenagrionidae was the most abundant family during the hot-dry season (Table S1 in Supplementary file).

\section{Adult composition (Objective 1)}

A total of 35 species and seven families were identified from a total of 2401 individual adults recorded, with the highest number of adults recorded during the hot-wet season (1294 individuals out of 35 species and seven families). However, six families and 33 species were found in the cold-dry season and, only six families and 28 species were recorded in the hot-dry season. The family Libelullidae had the highest abundance of adults recorded, followed by Coenagrionidae family during the entire sampling period. Brachythemis leucosticta recorded the highest number of individuals (315) during the entire sampling period followed by Trithemis arteriosa and Crocothemis erythraea with 296 and 191 individuals, respectively. However, T. arteriosa recorded the highest abundance during the cold dry season (85 individuals) and the hot dry season (84) whereas B. leucosticta recorded the highest abundance [177 individuals during the hot wet season]. 31 out of the 35 species identified recorded a low DBI score of 3 or less (Table S2 Table S3 \& Table S4 in Supplementary file). 
The results showed no significant difference in the diversity of nymphs $[\mathrm{X} 2(2, \mathrm{~N}=45)=2.9, \mathrm{p}>$ 0.05 ] among the three seasons during the entire study area, over the one-year period (Figure $2 \mathrm{~A}$ ). The results also showed no significant difference in the diversity of adults $[X 2(2, N=45)=1.3, p>0.05]$ among the three seasons during the entire study area, over the one-year period (Figure $2 \mathrm{~B}$ ).

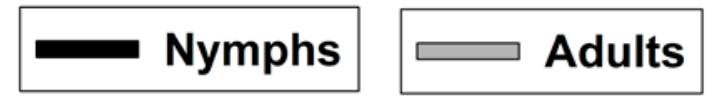

(A) Nymphs

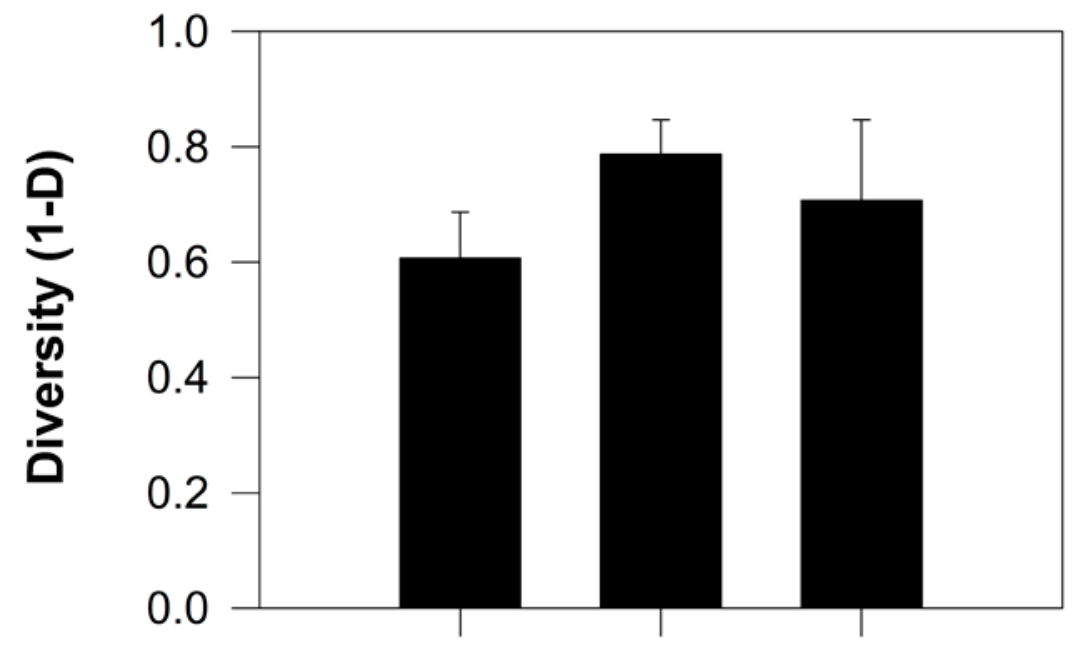

(B) Adults

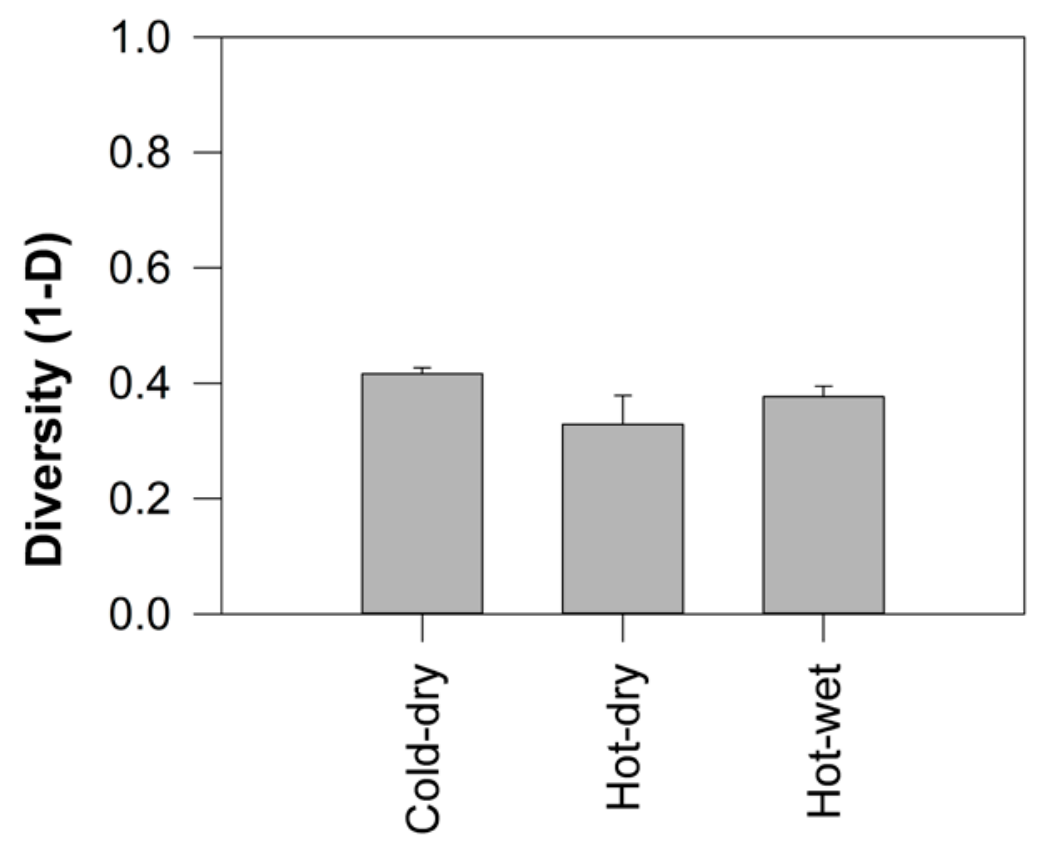

Sampling Occassion

Figure 2. Odonata species diversity among the three seasons sampled over a one-year period (May 2016 to April 2017), for nymphs (A) and adults (B). Error bars are based on standard deviations. 


\section{Relationships between Odonata and abiotic factors (Objective 2)}

We found no significant correlation between diversity indices and species richness with the physicochemical parameters (Table 1). Considering the relationship between odonate families and physicochemical parameters (Figure 3), $\mathrm{pH}$ was positively correlated with Libellulidae and Platycnemididae, whereas total dissolved solids (TDS) and conductivity (EC) were positively correlated with Libellulidae, Platycnemididae and Macromiidae. On the other hand, the Gomphidae family was found to be negatively correlated to TDS, EC, and $\mathrm{pH}$. We found a weak correlation between Coenagrionidae and water quality parameters. Conversely, we found no correlation between the family Aeshnidae and physicochemical parameters.

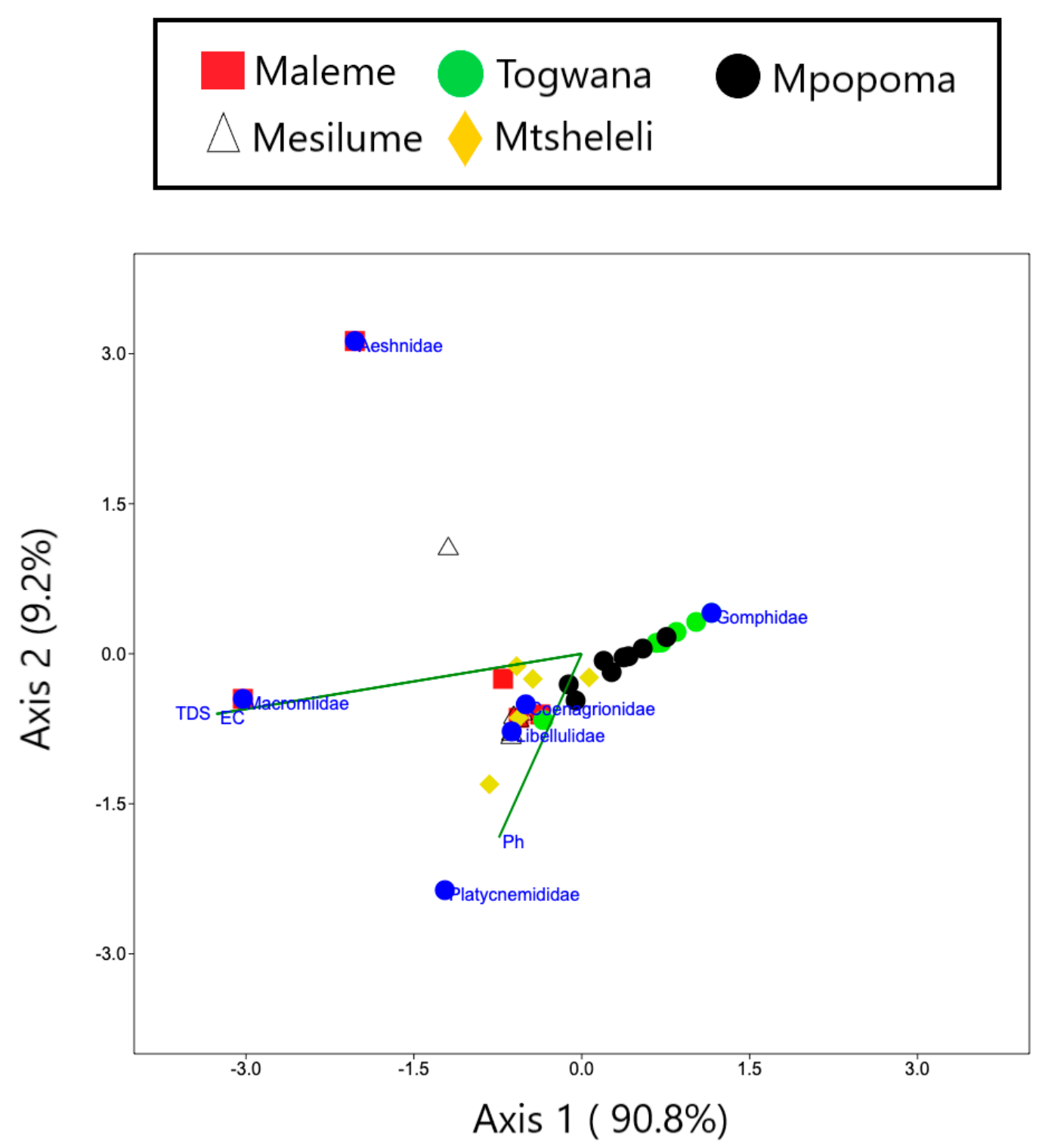

Figure 3. Canonical component analysis illustrating the associations between odonate nymphs and select physico-chemical parameters collected from five dams. 
Table 1: Spearman's correlation coefficient between physicochemical factors and aquatic insect diversity and richness at Dams in the Matopos World Heritage site.

\begin{tabular}{|l|l|l|}
\hline Parameter & Taxa S & Simpson Index (1-D) \\
\hline Total Dissolved Salts & -0.1303 & -0.1327 \\
\hline $\mathrm{pH}$ & 0.07736 & 0.14116 \\
\hline Conductivity $\left(\mu \mathrm{s} \mathrm{cm}^{-1}\right)$ & -0.1303 & -0.1327 \\
\hline
\end{tabular}

Gomphidae were found in higher percentages in sandy microhabitats $(>95 \%)$ and gravel $(>50 \%)$ than all other habitats sampled. Aeshnidae Families were found only where a detritus bottom substrate was present, with or without the presence of aquatic plants. Macromiidae and Platycnemididae were rare across all seasons (Figure 4).
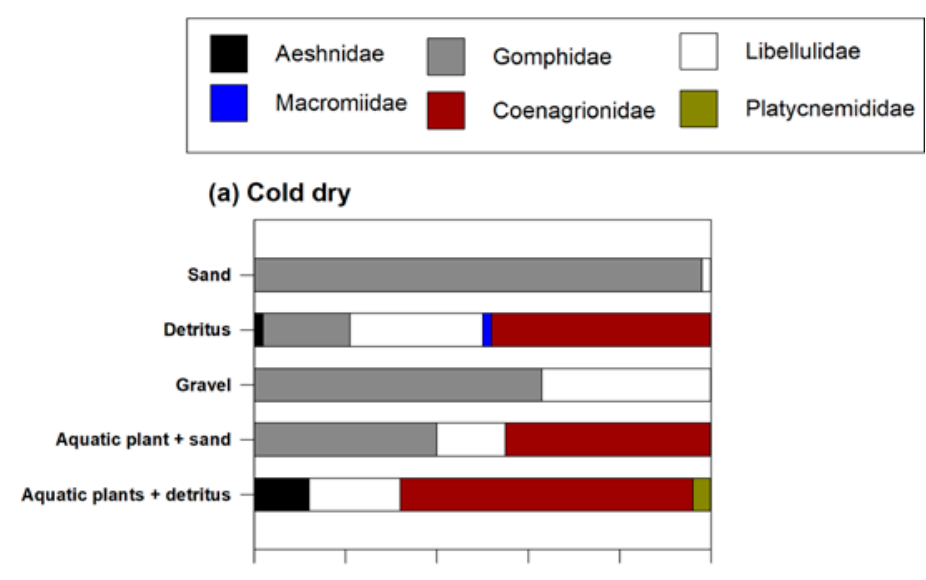

(b) Dry season

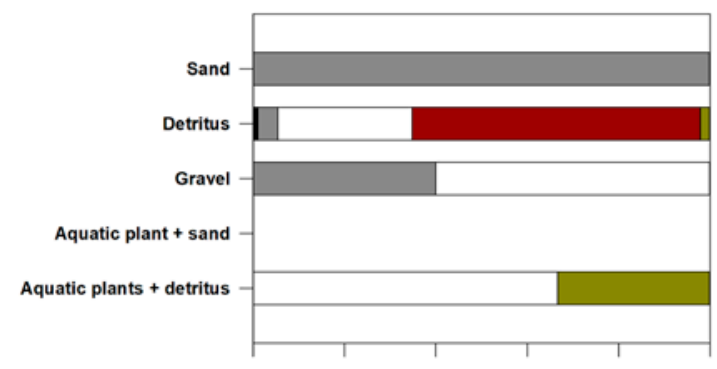

(c) Hot wet

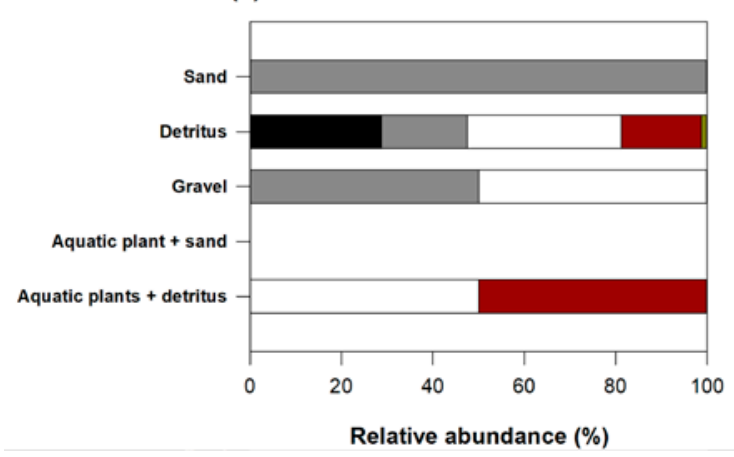

Figure 4. Relative abundances of nymphs in five substrata during three sampling times in the Matobo National Park. 
The indicator value analysis showed that Coenagrionidae, Libellulidae and Aeshnidae families were all significantly associated with detritus while the Gomphidae family was found to be significantly associated with sandy substrates (Table 2).

Table 2: IndVal analysis of Odonata nymphs associated with specific habitat types. Only significant $(p<0.05)$ habitat associations are presented. The significance of IndVal indices was assessed using 10,000 Monte Carlo permutations.

\begin{tabular}{|l|l|l|l|l|}
\hline Taxa & Habitat & indval & pvalue & freq \\
\hline Coenagrionidae & Detritus & 0.22 & 0.001 & 53 \\
\hline Libellulidae & Detritus & 0.14 & 0.009 & 47 \\
\hline Aeshnidae & Detritus & 0.07 & 0.043 & 14 \\
\hline Gomphidae & Sand & 0.49 & 0.001 & 56 \\
\hline
\end{tabular}

\section{Threat assessments (Objective 3)}

Considering overall threats averaged across all dams, natural system modifications driven by fires and fire suppression as well as dams and water management, were identified as the most significant threats on Odonata around Lentic habitats in Matobo National Park [contributing 18\% of all assessed threats] (Table. S5 in Supplementary file). Other factors that showed a significant impact include Agriculture expansion and intensification, specifically, the livestock from surrounding the communities which are left to drink water and graze around the dams within the National Park and, residential development (for Tourism and recreation areas), which contributed $\sim 16 \%$ of all assessed threats. Habitat shifting and alterations, human intrusions and disturbances through recreational activities, pollution from garbage and solid waste and, invasive alien plant species (Figure S1 in Supplementary File) were also identified as the threats to Odonata around Lentic habitats in Matobo National Park, contributing $\sim 10 \%$ of all assessed threats. It was also observed that over-exploitation of aquatic species is also a potential threat to Odonata around Lentic habitats in Matobo National Park contributing $\sim 7.5 \%$ of all assessed threats (Figure 5, Table S5 in Supplementary file).

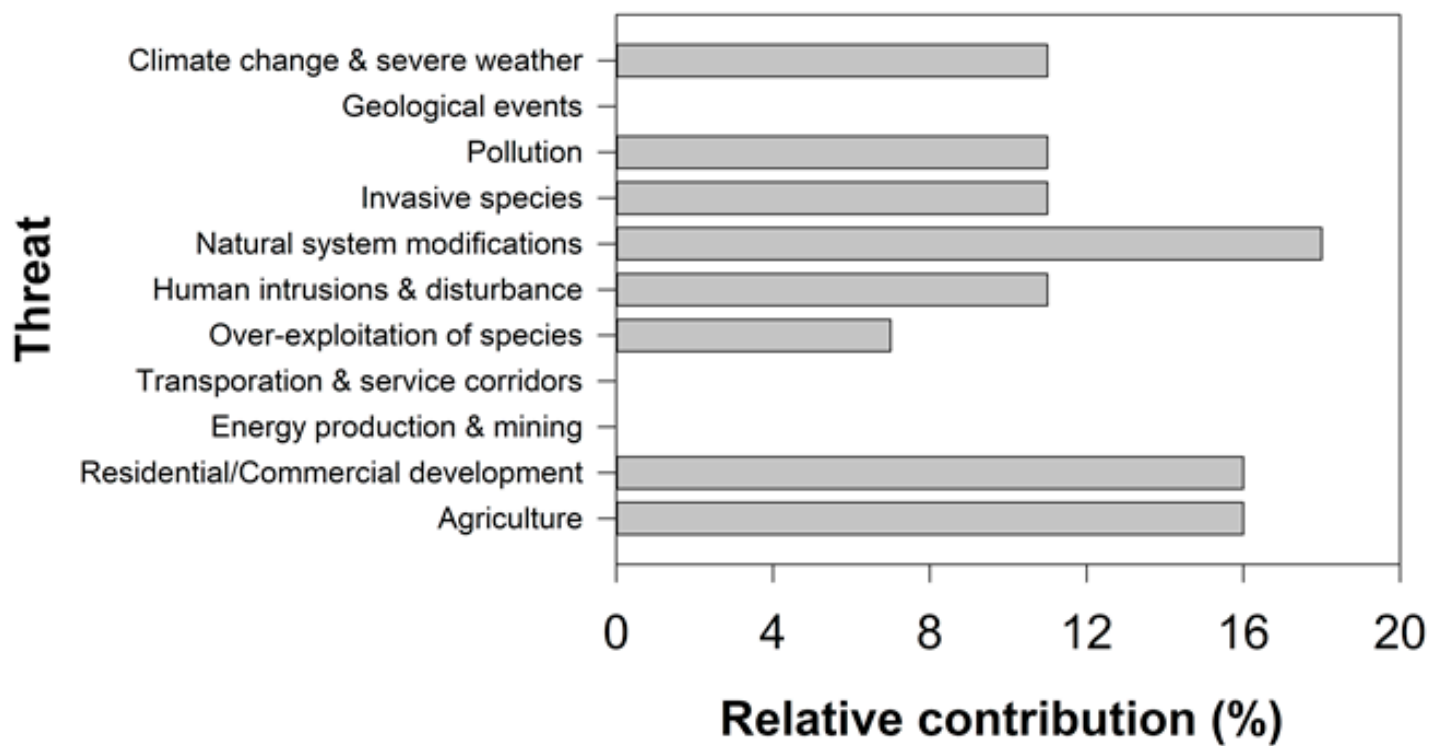

Figure 5. Direct threats impact of odonates at lacustrine systems in Matobo National Park. Only impacts $>5 \%$ are present. 


\section{Discussion}

We investigated the community assembly of Odonata species occurring in lacustrine systems in a World Heritage Site (Matobo National Park). Our results revealed that the nymphs and adults of the family Libellulidae and Coenagrionidae were the most abundant, and over $80 \%$ of the species recorded had low DBI score indicating that the Odonata assemblage in lacustrine systems are mostly composed of wide spread generalist species, as documented in parts of the African continent (Mafuwe \& Moyo, 2020). Additionally, Agricultural expansion and intensification, Residential and Commercial development, Habitat shifting and alteration through climate change and, human encroachment and natural system modifications were identified as major threats to odonate and other freshwater organisms in Matobo National Park. Contrary to our predictions, we found no significant differences in the diversity of nymphs and adults across all seasons. Our study makes a huge contribution to Odonata research and conservation initiatives in that it provides baseline data that can be used to monitor Odonata populations and distributions in aquatic habitats in the Matobo world heritage site.

\section{Nymph and Adult compositions}

Gomphidae were the most abundant nymphs, while Libellulidae were the most abundant adults. Specifically, the species, Brachythemis leucosticta in the Libellulidae family recorded the highest number of individuals during the entire sampling period followed by Trithemis arteriosa and Crocothemis erythraea. The abundance of the species mentioned above is tenable, considering that these three species are widespread in Africa (IUCN, 2020; Dijkstra \& Clausnitzer 2014; Damm \& Hadrys 2012). The results also revealed that over $80 \%$ of the odonate assemblages at the dams in Matobo World heritage site have a low DBI score of 3 or less. This also indicates that the assemblage composed of mostly of common, widespread generalists odonate species which are tolerant to human disturbance (Simaika \& Samways, 2009; Samways, 2008). On the other hand, some sensitive species, which are not very tolerant of disturbed areas and were last recorded in Matopos in the year 1980. e.g., Agriocnemis pinheyi (Pinhey wisp) and Bradinopyga cornuta (Horned rock dweller) were not recorded during this study. However, we only considered a short temporal scale of one year between 2016 and 2017.

Considering seasonal variation in diversity, there were no significant differences in the diversity of nymphs and adults across all seasons. The lack of seasonal variation may be explained by the fact that dams act as reservoirs for rainwater (Kosterin, 2010; Loureiro \& Pontes, 2013) and they provide microhabitats, perch sites and artificial breeding sites that can support many species all year round. As such lentic habitats may support the same diversity of species across all seasons. However, with limited sampling the data in this study need to be interpreted with caution as sampling was done over one year between May 2016 and April 2017. It was reported that Zimbabwe experienced a severe drought in the year 2016, which was declared a national disaster with the drought being so severe in the southern parts of Zimbabwe (Government of Zimbabwe, 2017). This was also followed by some heavy flooding from the effects of cyclone Dineo in early 2017. During alternation of these extreme climates, odonates are known to sometimes alter their behaviour. For instance, some species may be present during wet years, but completely vanish where there have been ecosystem disruptions and extreme disturbances, only to appear and recover again when seasons have stabilized. Most of the freshwater habitats are also degraded or may also disappear during alternation of these extreme events (Abrahams et al. 2013) and recovery of odonate populations where habitats have been destroyed is very slow (Samways, 2010). Frequent sampling, over a longer period may therefore be able to reveal other patterns that were not revealed during this study. 


\section{Relationships between Odonata and abiotic factors}

Diversity and species richness were not correlated to physicochemical parameters. These findings are similar with results in a study by Ab Hamid, Salmah, \& Nurul Huda (2016), who found no significant correlation between physico-chemical parameters (e.g. pH and TDS) and total abundance of Odonata nymphs. Notwithstanding, we only collected three abiotic variables thus, we possibly missed some of the variables that may have been critical as drivers of odonate nymph diversity. For example, dissolved oxygen, air temperatures, water temperature and flow rate have been documented as factors that significantly impact odonate diversity (Adu \& Oyeniyi, 2019). Similarly, our taxonomic resolution for the odonate nymphs may have impacted the relationships between physicochemical parameters and odonate nymphs. Specifically, we identified the odonates nymphs to morphospecies. Nevertheless, Odonata nymphs are difficult to determine up to species level, especially at the early instar level. This is because the characteristics used to identify nymphs are not fully developed for early instars (Tennessen, 2019). Fraser (1956) states that the best method is to rear them in for correct identification up to species.

We found the physicochemical quality parameters were related to odonate families. For example, $\mathrm{pH}$ was positively correlated with Libellulidae and Platycnemididae, whilst total dissolved solids (TDS) and conductivity (EC) were positively correlated with Libellulidae, Platycnemididae and Macromiidae. Many species of Libellulidae and Platycnemididae are known to be salt-tolerant, and many are generalists that can inhabit in almost all kinds of water, whether acidic, alkaline, brackish or saline (Lakhiar \& Panhwar, 2015; Saeed et al., 2016). However, the Gomphidae family was found to be negatively correlated to TDS, EC and pH. According to Ab Hamid, Salmah, \& Nurul Huda (2016), gomphids thrive better in freshwaters compared to brackish waters. Additionally, Gomphidae are sensitive to pollution and environmental disturbance (Bouchard, 2004).

The results showed the highest percentage of Gomphidae nymphs were found in the sandy substrates followed by the gravel bottom substrates across all seasons (Figure 4). The Indval analysis also showed the Gomphidae family to be significantly associated with sandy bottom substrates. Gomphidae as sedentary burrowers are found where there is sand, silt, mud or gravel to burrow into (Leipelt et al., 2010; Palatov, Chertoprud, \& Frolov, 2016; Thorp \& Covich, 2015).

The Coenagrionidae and Platycnemididae nymphs were recorded in aquatic plants. Coenagrionidae and Platycnemididae species are known to be found amongst submerged vegetation, such as willow roots and reeds (Thorp \& Covich, 2015). Females lay their eggs in plant tissue, and the nymphs cling on to the submerged plants (Thorp \& Covich, 2015). Coenagrionidae nymphs were also found in detritus substrates possibly because Coenagrionidae nymphs are known to survive in detritus even when water sources dry up and some dams like Maleme dam were observed to be very sluggish with a lot of detritus especially during the dry season when they were drying up.

Aeshnidae was only found where there was a detritus bottom (with or without aquatic plants present). Aeshnids are known to prefer a wide range of habitats, including brackish and sluggish waters characterized by mud and detritus (Hawking et al., 2004). Aeshindae are also known as climbers adapted to living on vascular hydrophytes or detrital debris (e.g., overhanging branches, roots and vegetation along streams, submerged brush in lakes) with modifications for moving vertically on stem-type surfaces. In this study, a large number of samples were collected from detritus bottom substrate. The muddy substrates may be a result of the deposits of animal waste from the livestock and wildlife drinking from the dams. The organic detritus was also composed of fine silt mud possibly brought down by rivers and land runoff.

Macromiidae was only recorded during the cold, dry season where there was mud and detritus. Macromiidae are known to occur in mud, silt, gravel, rocks and litter in the benthic zone (Laughlin et al., 2018), however, only a few species of Macromiidae species are found in Africa and most reproduce in flowing waters, which can explain why only one individual was recorded at these lentic habitats throughout the study period.

Libellulidae was found across most of the microhabitats across all seasons. Many species in the Libellulidae are widespread, and the family has many generalist species which are known to occupy a 
wide range of still or sluggish waters; including streams that dry to pools in the outback, riverine pools, lagoons, lakes, boggy seepages, swamps and permanent ponds (Samway 2008; Dijkstra \& Clausnitzer, 2014).

\section{Threat assessments and Conservation of Odonates}

Considering threats to Odonata around lentic habitats in Matopos National Park we found natural system modifications to be the most significant threats. The likely modifications in MNP are likely related to hydroperiods (water level fluctuations) of dams that are affected by rainfall patterns in Southern Africa, as documented by other researchers (sensu Deacon, Samways, \& Pryke, 2018; Briggs et al. 2019; Jooste, Samways, \& Deacon, 2020). According to IUCN (2020), the 'natural system modifications' is a threat category which covers a wide range of activities that convert or degrade habitats largely as a result of human management. The dominant threat in this category for aquatic systems is damming, which fragment river systems, alter flows and sedimentation patterns, and cause mortality and decline in aquatic organisms (IUCN, 2020). For example, large hydroelectric and flood control dams which flooded 102,000 hectares of wetlands in the Columbia Basin possibly eliminated populations of almost all dragonfly species on the Basin list and; the modification of the shores of the Kootenay and Columbia rivers through dam construction has eliminated many habitats for Argia emma, Ophiogomphus occidentis and Macromia magnifica. Similar natural system modifications have been implicated in the decline of other freshwater invertebrates at many locales (Vinson, 2001).

Agriculture expansion \& intensification, specifically, the livestock from surrounding the communities which are often left to drink water and graze around the dams within the National Park (K. Mafuwe, Personal observation, November 2016), and development of tourism facilities and recreation areas, also contributed approximately $16 \%$ of all assessed threats. Livestock grazing in the national park has been observed and mentioned by a number of tourists and visitors to the park as early as the year 2012 (Newsday - September 4, 2012; Zimfieldguide.com, n. d). Cattle grazing and trampling around aquatic habitats, has been known to increase habitat alteration by destroying vegetation, reducing plant cover, destroying soil structure and, increasing surface runoff of water and siltation (Dunne, Western, \& Dietrich, 2011; Pelinson, Garey, \& Rossa-Feres, 2016) e.g. observed around Mesilume dam (Figure S2 in Supplementary File). Dams around Matopos National Park are used as camping locations and for recreational activities such as picnic and fishing sites by tourists. Direct and indirect human activities including tourism and recreational activities are known to cause destruction of the freshwater habitats through pollution, littering and destruction of vegetation. This consequently has a significant impact on aquatic organisms. Similar impacts may also result from the human intrusions and disturbance and, pollution threats which were observed to contribute about $10 \%$ of all assessed threats. For example, Spyra \& Strzelec (2019) confirmed that recreational activities alter some characteristic of environments such as altering the substrates for perching such as leaf deposits and plants, impacting on benthic invertebrate population.

Habitat shifting \& alteration and invasive alien species were also identified as the threats to Odonata around Lentic habitats in Matobo National Park and also contributed $\sim 10 \%$ of all assessed threats. Similarly, invasive alien species have been recognized as a threat to Red-Listed dragonflies in countries like South Africa's (Samways \& Taylor, 2004). Elsewhere, García et al. (2010) also notes that invasive species threaten freshwater species. Further, anthropogenically-induced climate change increases the frequency and occurrence of droughts which subsequently result in habitat shifting $\&$ alterations. The fluctuating water levels not only affect the quality of the water for example by changing the acidity levels but, also impact on the quality of the surrounding vegetation, possibly resulting in a loss of some Odonata species, e.g. Lestes dryas Kirby, 1890 a species of dragonfly which declined due to climate change which had an impact on many habitat factors, in England and Ireland around the year 1980 (Moore, 1980). The fluctuations in temperature may also influence changes in geographical distributions, through a shifting of species' fundamental niches, changes in the distribution of suitable habitat and variation in the dispersal ability of species (Hassall \& Thompson, 
2008). We also recorded that over-exploitation of species as a potential threat to Odonata around Lentic habitats in Matobo National Park contributing 7.5\% of all assessed threats. More specifically, the use of gillnets for fishing nets was observed at Maleme dams during the study period. The use of fishing nets is particularly destructive to the none target species and their freshwater habitats and therefore the impact extends further than just to the fish. Considering the threats to the Matobo National Park, we recommend that the Zimbabwe National Parks and Wildlife Management Authority embarks on more stringent regulations on fishing practices, invasive species management, and abstraction of natural resources in the Matobo Nation Park. Future construction of tourism facilities should also aim at minimizing the potential impacts of land-clearing and modifications of the landscape during the construction of tourism facilities, such as removal of vegetation, changes in water flows, and destruction or alteration of breeding and feeding grounds of freshwater species. In addition, such habitat alterations could to be compensated by additional habitats. Even further, wetlands could be promoted through tourism facilities.

Summarily, this study has documented the seasonal diversity and distribution of odonates (nymphs and adults) in an understudied protected area. A number of species and families recorded in this study are known to have wide range and very tolerant of polluted and disturbed waters e.g., Trithemis arteriosa and Crocothemis erythraea and many other species of the Libellulidae and Platycnemididae families. Additionally, over $80 \%$ of the species recorded have a low DBI score indicating that the Odonata assemblage at the lacustrine systems is mostly comped of widespread generalist species. Some sensitive species, which are not very tolerant of disturbed areas and were last recorded in Matopos in the year 1980 were also not recorded during this study. However, only a short temporal scale (2016/2017) was considered. Considering Zimbabwe experienced severe weather extremes during the study period, long monitoring data over long temporal scales are warranted. The threats on Odonata species and the freshwater habitats, identified in this study provide a basis for call to actions to protect freshwater biodiversity in Zimbabwe. Because Odonata species have been identified as key indicator species, habitat protection and restoration are the most important steps towards conservation of these species. It is necessary to maintain the structural integrity of both larval and adult habitats, i.e. water bodies and their surrounding landscape.

Broadly, considering the environmental and anthropogenic pressures in water resources and the world over, our findings stress the need for more focused baseline studies documenting diversity and abundances of freshwater species; these baseline studies will allow ecologist and environmental managers to predict the effect of future environmental and anthropogenic perturbations. Further, considering that odonates are not listed in many conservation strategies in most African countries, there is need for baselines studies to explore the conservation strategies for small taxa animals such as odonates. Our results will be useful to conservation managers in the Matobo National Park and other protected areas in Sub- Saharan Africa and the world.

\section{Acknowledgements}

We would like to thank the two anonymous reviewers for their invaluable comments that were useful in improving the quality of this paper. This research was co-funded by the Tropical Biology Association under the Small Grants Scheme and the Natural History Museum of Zimbabwe. Any opinion, findings and conclusions or recommendations expressed in this material are those of the authors and do not necessarily reflect the views of the funders. 


\section{References}

Ab Hamid, S., Salmah, M., \& Nurul Huda, A. (2016). Composition and distribution of odonata larvae and its relationship with physicochemical water quality in northern peninsular Malaysia. Malaysian Journal of Science, 35, 198-209. https://doi.org/10.22452/mjs.vol35no2.9

Abrahams, C., Brown, L., Dale, K., Edwards, F., Jeffries, M., Klaar, M., ... \& Murphy, J. (2013). The impact of extreme events on freshwater ecosystems. Ecological Issues; Jones, I., Ed.; British Ecological Society: London, UK, 68.

Acquah-Lamptey, D., Kyerematen, R., \& Owusu, E. O. (2013). Using odonates as markers of the environmental health of water and its land related ecotone. International Journal of Biodiversity and Conservation, 5(11), 761-769. https://doi.org/10.5897/IJBC2013.0600

Adu, B. W., \& Oyeniyi, E. A. (2019). Water quality parameters and aquatic insect diversity in Aahoo stream, southwestern Nigeria. The Journal of Basic and Applied Zoology, 80(1), 15. https://doi. org/10.1186/s41936-019-0085-3

Bernard, R., \& Daraż, B. (2018). New records of dragonflies (Odonata) in Zambia. African Invertebrates, 59(2), 165-193. https://doi.org/10.3897/afrinvertebr.59.29021

Bouchard, R. W. J. (2004). Guide to aquatic macroinvertebrates of the Upper Midwest. Water Resources Center.

Briggs, A., Pryke, J. S., Samways, M. J., \& Conlong, D. E. (2019). Macrophytes promote aquatic insect conservation in artificial ponds. Aquatic Conservation: Marine and Freshwater Ecosystems, 29(8), 1190-1201. https://doi.org/10.1002/aqc.3157

Burgess, N., Küper, W., Mutke, J., Brown, J., Westaway, S., Turpie, S., Meshack, C., Taplin, J., McClean, C., \& Lovett, J. C. (2005). Major gaps in the distribution of protected areas for threatened and narrow range Afrotropical plants. Biodiversity \& Conservation, 14(8), 1877-1894. https://doi. org/10.1007/s10531-004-1299-2

Cardoso, P., Barton, P. S., Birkhofer, K., Chichorro, F., Deacon, C., Fartmann, T., Fukushima, C. S., Gaigher, R., Habel, J. C., Hallmann, C. A., Hill, M. J., Hochkirch, A., Kwak, M. L., Mammola, S., Ari Noriega, J., Orfinger, A. B., Pedraza, F., Pryke, J. S., Roque, F. O., ... Samways, M. J. (2020). Scientists' warning to humanity on insect extinctions. Biological Conservation, 242, 108426. https://doi.org/10.1016/j.biocon.2020.108426

Clausnitzer, V. (2003). Dragonfly communities in coastal habitats of Kenya: indication of biotope quality and the need of conservation measures. Biodiversity \& Conservation, 12(2), 333-356. https://doi.org/10.1023/A:1021920402913

Clausnitzer, V., Simaika, J. P., Samways, M. J., \& Daniel, B. A. (2017). Dragonflies as flagships for sustainable use of water resources in environmental education. Applied Environmental Education \& Communication, 16(3), 196-209. https://doi.org/10.1080/1533015X.2017.1333050

Córdoba-Aguilar, A. (2008). Dragonflies and Damselflies: Model Organisms for Ecological and Evolutionary Research. OUP Oxford.

Damm, S., \& Hadrys, H. (2012). A dragonfly in the desert: genetic pathways of the widespread Trithemis arteriosa (Odonata: Libellulidae) suggest male-biased dispersal. Organisms Diversity \& Evolution, 12 (3), 267-279. https://doi.org/10.1007/s13127-012-0079-1

Deacon, C., Samways, M. J., \& Pryke, J. S. (2018). Artificial reservoirs complement natural ponds to improve pondscape resilience in conservation corridors in a biodiversity hotspot. PloS one, 13(9), e0204148.

Deacon, C., Samways, M. J., \& Pryke, J. S. (2020). Determining drivers of dragonfly diversity patterns and the implications for conservation in South Africa. Biological Conservation, 245, 108548. https://doi.org/10.1016/j.biocon.2020.108548

Dijkstra, K. (2007). The name-bearing types of Odonata held in the Natural History Museum of Zimbabwe, with systematic notes on Afrotropical taxa. Part 2: Zygoptera and descriptions of new species. International Journal of Odonatology - INT J ODONATOL, 10. https://doi.org/10.1080/1 3887890.2007 .9748296

Dijkstra, K., \& Clausnitzer, V. (2014). The Dragonflies and Damselflies of Eastern Africa: Handbook for all Odonata from Sudan to Zimbabwe. Studies in Afrotropical Zoology, 298, 1-264.

Dijkstra, K., Kipping, J., \& Mézière, N. (2015). Sixty new dragonfly and damselfly species from Africa (Odonata). Odonatologica, 44, 447-678. https://doi.org/10.5281/zenodo.35388 
Dijkstra, K.-D. B., Monaghan, M. T., \& Pauls, S. U. (2014). Freshwater Biodiversity and Insect Diversification. Annual Review of Entomology, 59, 143-163. https://doi.org/10.1146/annurev-ento-011613-161958

Dube, T., Makaka, C., \& Sibanda, Z. (2010). An assessment of the effect of industrial and sewage effluent on aquatic invertebrates: a case study of a southern urban stream, Zimbabwe. Journal of Sustainable Development, 3(2), 210-214.

Dufrêne, M., \& Legendre, P. (1997). Species Assemblages and Indicator Species:the Need for a Flexible Asymmetrical Approach. Ecological Monographs, 67(3), 345-366. https://doi. org/10.1890/0012-9615(1997)067[0345:SAAIST]2.0.CO;2

Dunne, T., Western, D., \& Dietrich, W. E. (2011). Effects of cattle trampling on vegetation, infiltration, and erosion in a tropical rangeland. Journal of Arid Environments, 75(1), 58-69. https://doi. org/10.1016/j.jaridenv.2010.09.001

Ervin, J. (2003). WWF: Rapid Assessment and Prioritization of Protected Area Management (RAPPAM) Methodology.

Fraser, I. M. S. (1956). Handbooks for the Identification of British Insects (1st ed., Vol. 1). Royal Entomological Society.

Gambiza, J., \& Nyama, C. (2006). Country Pasture/Forage Report (FAO).

García, N., Cuttelod, A., \& Malak, D. A. (2010). The Status and Distribution of Freshwater Biodiversity in Northern Africa. IUCN.

Government of Zimbabwe. (2017). Zimbabwe: 2016-2017 Drought Disaster Domestic and International Appeal for Assistance. Government of Zimbabwe, Harare.

Hassall, C., \& Thompson, D. (2008). The effects of environmental warming on Odonata: A review. International Journal of Odonatology - INT J ODONATOL, 11. https://doi.org/10.1080/13887890 .2008.9748319

Hawking, J., Suhling, F., Wilson, K., Theischinger, G., \& Reels, G. (2004). Underwater and epilithic oviposition by Australian Aeshnidae (Odonata). International Journal of Odonatology, 7(1), 3336. https://doi.org/10.1080/13887890.2004.9748192

IUCN. (2017). The IUCN Red List of Threatened Species. Version 2017-2.

IUCN. (2020). The IUCN Red List of Threatened Species. Version 2020-2. https://www.iucnredlist. org. Downloaded on 09 July 2020.

Jooste, M. L., Samways, M. J., \& Deacon, C. (2020). Fluctuating pond water levels and aquatic insect persistence in a drought-prone Mediterranean-type climate. Hydrobiologia, 847(5), 1315-1326. https://doi.org/10.1007/s10750-020-04186-1

Kalkman, V., Clausnitzer, V., Dijkstra, K., Orr, A., Paulson, D., \& Tol, J. (2008). Global diversity of dragonflies (Odonata) in freshwater. In Hydrobiologia (Vol. 595, pp. 351-363). https://doi. org/10.1007/978-1-4020-8259-7_38

Kosterin, O. (2010). A glance at the Odonata of the Cambodian coastal mountainous regions: end of dry season in 2010.

Lakhiar, A., \& Panhwar, W. (2015). On the identity of Neurothemis tullia (Drury, 1773) (Odonata: Libellulidae). Arquivos Entomolóxicos, 14:, 169-171.

Laughlin, M., Martin, J., Liesch, P., \& Olson, E. (2018). Dragonfly (Odonata: Corduliidae, Macromiidae, Gomphidae, Aeshnidae) and Damselfly (Odonata: Calopterygidae) Exuviae Observed at Record Heights in Pinus strobus and Picea abies Canopies. The Great Lakes Entomologist, 51(1), 26-29.

Leipelt, K. G., Suhling, F., \& Gorb, S. N. (2010). Ontogenetic shifts in functional morphology of dragonfly legs (Odonata: Anisoptera). Zoology, 113(6), 317-325. https://doi.org/10.1016/j. zool.2010.05.004

Loureiro, N. de S., \& Pontes, L. (2013). The Trithemis nigra (Odonata: Libellulidae) of Príncipe Island, Gulf of Guinea. African Journal of Ecology, 51(1), 180-183. https://doi.org/10.1111/aje.12013

Mafuwe, K \& Moyo, S (2020) Dragonfly (Odonata) community structure in the Eastern Highlands Biodiversity Hotspot of Zimbabwe: potential threats of land use changes on freshwater invertebrates, International Journal of Odonatology, https://doi.org/10.1080/13887890.2020.1768156

Makaure, J., Makaka, C., Sithole, M., Moyo, D. Z., Baudi, I., Mufandaedza, E., \& Bwangamoi, O. (2015). Assessment of upper thermal tolerances of naiads of two odonate families: Coenagrionidae and Libellulidae in Lake Kariba, Zimbabwe. Applied Zoology, 80, 31201-31206. 
Martens, A. (2002). Group oviposition in three platycnemidid species (Odonata: Platycnemididae). International Journal of Odonatology, 5(1), 75-80. https://doi.org/10.1080/13887890.2002.9748177

Matobo Hills Management Plan. (2015). Matobo-Hills-WHS-Management-Plan-2015-2019.pdf (p. 36).

McCrae, A. W. R., \& Corbet, P. S. (1982). Oviposition behaviour of Tetrathemis polleni (Selys): a possible adaptation to life in turbid pools (Anisoptera: Libellulidae). Odonatologica, 11(1), 23-31. http://natuurtijdschriften.nl/record/591565

Moore, N. W. (1980). Lestes dryas kirby - a declining species of dragonfly (odonata) in need of conservation: Notes on its status and habitat in England and Ireland. Biological Conservation, 17(2), 143-148. https://doi.org/10.1016/0006-3207(80)90044-0

Morris, E. K., Caruso, T., Buscot, F., Fischer, M., Hancock, C., Maier, T. S., Meiners, T., Müller, C., Obermaier, E., Prati, D., Socher, S. A., Sonnemann, I., Wäschke, N., Wubet, T., Wurst, S., \& Rillig, M. C. (2014). Choosing and using diversity indices: insights for ecological applications from the German Biodiversity Exploratories. Ecology and Evolution, 4(18), 3514-3524. https:// doi.org/10.1002/ece3.1155

Mutasa, M., \& Ndebele-Murisa, M. (2015). Biodiversity and human development in Zimbabwe (pp. 199-241).

Nagy, H. B., László, Z., Szabó, F., Szőcs, L., Dévai, G., \& Tóthmérész, B. (2019). Landscape-scale terrestrial factors are also vital in shaping Odonata assemblages of watercourses. Scientific Reports, 9(1), 18196. https://doi.org/10.1038/s41598-019-54628-7

Newsday (2012) Lifeline for Matobo cattle. Newsday - September 4, 2012. Retrieved 30 September 2020 from https://www.newsday.co.zw/2012/09/2012-09-04-lifeline-for-matobo-cattle/.

Oksanen, J., Blanchet, F. G., Kindt, R., Legendre, P., O'Hara, R., Simpson, G., Solymos, P., Stevens, M., \& Wagner, H. (2010). Package 'vegan': Community Ecology Package. Version 1.17-2.

Paice, R. L., Chambers, J. M., \& Robson, B. J. (2017). Native submerged macrophyte distribution in seasonally-flowing, south-western Australian streams in relation to stream condition. Aquatic Sciences, 79(1), 171-185. https://doi.org/10.1007/s00027-016-0488-x

Palacino Rodríguez, F., Palacino, D., Rache, L., Cordero-Rivera, A., Penagos, A., \& Lamelas-López, L. (2018). Larval development and behavior of Rhionaeschna marchali Rambur (Anisoptera: Aeshnidae) under captivity conditions. International Journal of Odonatology, 1-16. https://doi.or $\mathrm{g} / 10.1080 / 13887890.2018 .1437478$

Palatov, D. M., Chertoprud, M. V., \& Frolov, A. A. (2016). Fauna and types of soft-bottom macrozoobenthic assemblages in watercourses of mountainous regions on the eastern Black Sea coast. Inland Water Biology, 9(2), 150-159. https://doi.org/10.1134/S1995082916020140

Pelinson, R. M., Garey, M. V., \& Rossa-Feres, D. C. (2016). Effects of grazing management and cattle on aquatic habitat use by the anuran Pseudopaludicola mystacalis in agro-savannah landscapes. PloS one, 11(9), e0163094.

Pinhey, E. (1961). A Survey of the Dragonflies (Order Odonata) of Eastern Africa. London, UK: British Museum, pp 214.

Pinhey, E. C. (1984). A check-list of the Odonata of Zimbabwe and Zambia. Bulawayo, Zimbabwe: National Museums and Monuments of Zimbabwe.

Pritchard, G., \& Kortello, A. (1997). ROOSTING, PERCHING, AND HABITAT SELECTION IN ARGIA VIVIDA HAGEN AND AMPHIAGRION ABBREVIATUM (SELYS) (ODONATA: COENAGRIONIDAE), TWO DAMSELFLIES INHABITING GEOTHERMAL SPRINGS. The Canadian Entomologist, 129(4), 733-743. https://doi.org/10.4039/Ent129733-4

R Core Team (2019). A language and environment for statistical computing. R Foundation for Statistical Computing, Vienna, Austria. http://www.R-project.org/.

Rehfeldt, G. E. (1990). Anti-predator strategies in oviposition site selection of Pyrrhosoma nymphula (Zygoptera: Odonata). Oecologia, 85(2), 233-237. https://doi.org/10.1007/BF00319406

Remsburg, A. J., \& Turner, M. G. (2009). Aquatic and terrestrial drivers of dragonfly (Odonata) assemblages within and among north-temperate lakes. Journal of the North American Benthological Society, 28(1), 44-56. JSTOR. https://doi.org/10.1899/08-004.1

Richards, O. W., \& Davies, R. G. (1977). Odonata (Dragonflies). In O. W. Richards \& R. G. Davies (Eds.), Imms' General Textbook of Entomology: Volume 2: Classification and Biology (pp. 494520). Springer Netherlands. https://doi.org/10.1007/978-94-011-6516-7_7 
Rodríguez-Tapia, G., Rocha-Ortega, M., \& Córdoba-Aguilar, A. (2020). An index to estimate the vulnerability of damselffies and dragonflies (Insecta: Odonata) to land use changes using niche modeling. Aquatic Insects, 0(0), 1-19. https://doi.org/10.1080/01650424.2020.1781191

Saeed, Dr. M., Zia, S. A., Farid, A., Khan, S., Badshah, T., Zada, N., \& Fazlullah, P. (2016). Libellulidae (Anisoptera) of upper Swat. Journal of Entomology and Zoology Studies, 227, 227-228.

Sagonda, B., \& Pegg, N. (2015). Gathering baseline data on the use and availability of ecosystem goods and services and the state of the ecosystem in nine administrative wards in the Matobo Hills World Heritage Site.

Salafsky, N., Salzer, D., Stattersfield, A. J., Hilton-Taylor, C., Neugarten, R., Butchart, S. H. M., Collen, B., Cox, N., Master, L. L., O’Connor, S., \& Wilkie, D. (2008). A Standard Lexicon for Biodiversity Conservation: Unified Classifications of Threats and Actions: Classifications of Threats \& Actions. Conservation Biology, 22(4), 897-911. https://doi.org/10.1111/j.1523-1739.2008.00937.x

Samways, M. J. (2008). Dragonflies and damselflies of South Africa (No. 70). Pensoft Publishers.

Samways, M. J. (2010). Impacts of extreme weather and climate change on South African dragonflies. Biodiversity and Ecosystem Risk Assessment 5, 78-84. https://doi.org/10.3897/biorisk.5.843

Samways, M. J., \& Steytler, N. S. (1996). Dragonfly (Odonata) distribution patterns in urban and forest landscapes, and recommendations for riparian management. Biological Conservation, 78(3), 279-288. https://doi.org/10.1016/S0006-3207(96)00032-8

Samways, M. J., \& Simaika, J. P. (2016). Manual of freshwater assessment: The South African Dragonfly biotic index. Pretoria, South Africa: South African National Biodiversity Institute.

Samways, M., \& Taylor, S. (2004). Impacts of invasive alien plants on Red-Listed South African dragonflies (Odonata). South African Journal of Science, 100.

Schriever, T. A., Cadotte, M. W., \& Williams, D. D. (2014). How hydroperiod and species richness affect the balance of resource flows across aquatic-terrestrial habitats. Aquatic Sciences, 76(1), 131-143. https://doi.org/10.1007/s00027-013-0320-9

Simaika, J. P., \& Samways, M. J. (2009). An easy-to-use index of ecological integrity for prioritizing freshwater sites and for assessing habitat quality. Biodiversity and Conservation, 18, 1171-1185.

Simpson, E. H. (1949). Measurement of Diversity. Nature, 163(4148), 688-688. https://doi. org/10.1038/163688a0

Spyra, A., \& Strzelec, M. (2019). The implications of the impact of the recreational use of forest mining ponds on benthic invertebrates with special emphasis on gastropods. Biologia, 74(8), 981992. https://doi.org/10.2478/s11756-019-00221-2

Suh, A. N., \& Samways, M. J. (2005). Significance of temporal changes when designing a reservoir for conservation of dragonfly diversity. Biodiversity \& Conservation, 14(1), 165-178.

Tarboton, W., \& Tarboton, M. (2019). A Guide to the Dragonflies and Damselflies of South Africa. Penguin Random House South Africa.

Tennessen, K. (2019). Dragonfly Nymphs of North America: An Identification Guide. https://doi. org/10.1007/978-3-319-97776-8

Thorp, J. H., \& Covich, A. P. (2015). Thorp and Covich's Freshwater Invertebrates (4th ed.). Elsevier. https://doi.org/10.1016/C2010-0-65590-8

Vinson, M. (2001). Long-Term Dynamics of an Invertebrate Assemblage Downstream from a Large Dam. Ecological Applications, 11, 711-730. https://doi.org/10.2307/3061112

Vorster, C., Samways, M. J., Simaika, J. P., Kipping, J., Clausnitzer, V., Suhling, F., \& Dijkstra, K.-D. B. (2020). Development of a new continental-scale index for freshwater assessment based on dragonfly assemblages. Ecological Indicators, 109, 105819. https://doi.org/10.1016/j. ecolind.2019.105819

Worthen, W. B., \& Morrow, P. H. (2016, September 22). Perch Selection by Three Cooccurring Species of Celithemis (Odonata: Libellulidae): Testing for a Competitive Hierarchy among Similar Species [Research Article]. Psyche; Hindawi. https://doi.org/10.1155/2016/9028105

Zimfieldguide.com (n. d). Matobo National Park, a UNESCO World Heritage Cultural Site. Retrieved 30 September 2020 from http://zimfieldguide.com/matabeleland-south/matobo-nationalpark-unesco-world-heritage-cultural-site 